\title{
Model Daycare Berbasis Attachment di Perkantoran
}

\section{Roza Lina ${ }^{1}$, Nenny Mahyuddin²}

1,2 Prodi Pendidikan Anak Usia Dini, Universitas Negeri Padang, Padang, Indonesia

\section{A R T I C L E I N F O}

Article history:

Received 27 January 2021

Revised 15 February 2021

Accepted 01 April 2021

Available online 25 April 2021

\section{Kata Kunci}

video gerak dan lagu,

lokomotor

Keywords:

motion video and song

locomotor

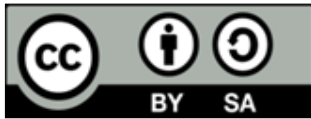

This is an open access article under the CC BY-SA license.

Copyright () Universitas Pendidikan Ganesha. All rights reserved.

\begin{abstract}
A B S T R A K
Berbagai kondisi orangtua yang mempunyai anak usia dini terutama yang berumur 0-2 tahun yang bekerja di kantor dalam mengasuh, merawat begitu juga dengan pemberian ASI berdampak terhadap attachment (kelekatan). Tujuan dari pengembangan ini menghasilkan buku panduan daycare perkantoran berbasis attachment yang valid, praktis, dan efektif. Adapun partisipan adalah pegawai yang mempunyai anak usia dini $(0-6$ tahun) sebanyak 16 orang dan pejabat di lingkungan perkantoran sebanyak 4 orang. Jenis penelitian adalah penelitian pengembangan yang menggunakan model 4-D terdiri dari 4 tahap yaitu pendefinisian, perancangan, pengembangan, dan penyebaran dengan metode pengumpulan data yaitu melalui observasi, wawancara, menyebarkan instrumen dan dokumentasi. Instrumen pengumpulan data berupa angket untuk uji validitas, praktikalitas, dan efektifitas. Teknik analisis data dalam penelitian ini menggunakan skala Likert dan rumus persen. Berdasarkan hasil uji validitas buku panduan model daycare di perkantoran berbasis attachment oleh para ahli diperoleh rata-rata $87 \%$ berada pada kategori sangat valid, hasil uji praktikalitas respon pejabat dan pegawai yang mempunyai anak usia dini diperoleh rata-rata persentase $88 \%$ pada kategori sangat praktis, dan hasil uji efektifitas respon pejabat (4 orang) dan pegawai yang mempunyai anak usia dini (16 orang) adalah $88 \%$ serta $91 \%$ di tempat penyebaran pada kategori sangat efektif. Dari penilaian hasil buku panduan diketahui dapat meningkatkan attachment orangtua dan anak. Berdasarkan hasil tersebut disimpulkan bahwa buku panduan model daycare di perkantoran berbasis attachment valid, praktis dan efektif serta dapat meningkatkan attachment antara orangtua dan anak.
\end{abstract}

\begin{abstract}
A B S T R A C T
Various conditions of parents who have early childhood, especially those aged 0-2 years who work in offices in caring, caring as well as breastfeeding have an impact on attachment. The purpose of this development is to produce an attachment-based office daycare guidebook that is valid, practical, and effective. The participants are employees who have early childhood (0-6 years) as many as 16 people and officials in the office environment as many as 4 people. This type of research is a development research that uses a 4-D model consisting of 4 stages, namely defining, designing, developing, and distributing the data collection methods through observation, interviews, distributing instruments and documentation. The data collection instrument was in the form of a questionnaire to test the validity, practicality, and effectiveness. The data analysis technique in this study used a Likert scale and the percent formula. Based on the validity test results of the daycare model guidebook in attachmentbased offices by experts, it was obtained that an average of $87 \%$ was in the very valid category, the practicality test results of the responses of officials and employees who had early childhood obtained an average percentage of $88 \%$ in the very practical category. , and the results of the effectiveness test for the response of officials (4 people) and employees who have early childhood (16 people) are $88 \%$ and $91 \%$ in the distribution place in the very effective category. From the assessment of the results of the manual, it is known that it can increase the attachment of parents and children. Based on these results, it is concluded that the daycare model guidebook in offices based on attachments is valid, practical and effective and can increase attachment between parents and children.
\end{abstract}

Copyright (C) Universitas Pendidikan Ganesha. All rights reserved 


\section{Pendahuluan}

Anak adalah harta yang paling berharga, setiap orangtua menyayangi anaknya dan menginginkan yang terbaik untuk anaknya. Pertumbuhan dan perkembangan anak adalah momen-momen yang tidak ingin dilewatkan oleh orangtua (Izza, 2020; Sukatin et al., 2020). Anak juga merupakan masa depan bangsa, dimana majunya suatu bangsa ada di tangan anak, usia dini menjadi usia yang sangat penting dalam menanamkan nilai moral, budaya dan nilai-nilai lainnya (Megawangi, 2014; Rakimahwati, 2012). anak adalah manusia yang memiliki keunikan yang perlu diperhatikan oleh orang dewasa, yang memiliki potensi dan memerlukan pelayanan yang sungguh-sungguh agar setiap potensi dapat menjadi landasan dalam menapaki tahap perkembangan berikutnya (Suryana, 2013). Anak usia dini memiliki karakteristik yang berbeda dengan orang dewasa, karena anak usia dini tumbuh dan berkembang dengan cara yang berbeda (Mahyuddin et al., 2016).

Penstimulasian tumbuh kembang anak dapat dilakukan di berbagai tempat, salah satunya Taman Penitipan Anak. Taman Penitipan Anak atau yang sekarang ini sering disebut daycare merupakan salah satu bentuk Pendidikan Anak Usia Dini pada jalur pendidikan nonformal sebagai wahana pelayanan pendidikan dan pengasuhan terhadap anak sejak lahir sampai dengan usia enam tahun dengan prioritas anak usia empat tahun ke bawah (Malinton, 2013). Daycare adalah layanan pendidikan usia dini 0-6 tahun nonformal dengan tujuan untuk memberikan pengasuhan anak yang ditinggal bekerja (Nuraini, 2018). Dari hasil laporan Dana Pertahanan Anak-anak negara Amerika pada tahun 2005, dengan jumlah 12 juta anak, termasuk enam juta bayi dan balita (Karkos, 2008). Dari jumlah tersebut 22 persen berada di pusat perawatan anak, 17 persen berada dalam penitipan keluarga dan yang lain memiliki pengasuhan di rumah atau dengan kerabat. Hal tersebut dikarenakan orangtua yang bekerja. Meskipun demikian, keberadaan daycare masih menjadi kajian yang serius oleh para praktisi, akademisi dan pemerhati anak mengingat program layanan ini bukan hanya berfungsi sebagai tempat pengasuhan substitusi saja, namun lebih dari itu daycare berfungsi sebagai tempat pendidikan dan pemberian stimulus perkembangan anak (Widiastuti, 2018).

Daycare sangat membantu orangtua ketika bekerja di kantor. Namun sampai sekarang, masih banyak perkantoran yang belum melaksanakannnya, jangankan taman penitipan anak, ruang laktasi saja tidak ada, dan kalaupun ada tidak dipergunakan sebagaimana mestinya bahkan disulap menjadi ruang bekerja. Program fullday adalah program yang sangat sesuai dengan daycare yang berada di lingkungan perkantoran, hanya saja diperlukan dukungan dari semua pihak agar berjalan lancar (AZIZ, 2017). Daycare harus memenuhi standar sarana dan prasarana yang baik dan lengkap (Widiastuti, 2018). Pilihan orangtua untuk menggunakan jasa penitipan anak, memastikan anak untuk mendapatkan yang terbaik dari segi pendidikan, pengasuhan, kebersihan, kesehatan dan keamanan (Rizkita, 2017). Sekarang ini banyak perkantoran yang memiliki pegawai yang masih dalam masa produktif, yang mempunyai anak dari 0 sampai 6 tahun. Permasalahan yang dialami yaitu terkait bagaimana anak mendapatkan ASI ekslusif, bagaimana tumbuh kembang anak mereka, dan bagaimana mereka tetap dekat dan lekat dengan anak-anak mereka dengan sepenuh kasih sayang, tanpa mengurangi kualitas mereka sebagai pegawai kantoran. Sementara dari hasil observasi dan wawancara yang penulis lakukan penulis menemukan anak yang menangis setiap orangtua berangkat ke kantor, anak menyusui tapi orangtua tidak focus kepada anak malah masih sibuk dengan handphone dan tidak berkomunikasi dengan anak, anak tidak mempedulikan kedatangan orangtua pada waktu pulang dari kantor, anak acuh pada saat orangtua memanggil, anak rewel di malam hari, anak dibawa ke kantor tapi kurang distimulus, anak bermain sendiri bahkan asyik bermain handphone

Pemberian ASI sangat menentukan kualitas kelekatan ibu-bayi dan berdampak seumur hidup baik dari segi pertumbuhan otak, perkembangan emosi, pembentukan empati, nurani dan perilaku sosial serta pembentukan rasa percaya diri, kognitif dan kreativitas. Kelekatan yang biasa juga dikenal dengan istilah attachment menurut Ainsworth dalam (Ervika, 2005) adalah ikatan emosional yang dibentuk seorang individu yang bersifat spesifik dalam suatu kedekatan yang bersifat kekal sepanjang waktu. Attachment harus dimulai dari dalam kandungan dan menjadi lebih penting pada saat kelahiran dan terus berlanjut pada tahun pertama bayi, karena anak-anak yang memiliki attachment yang erat dengan orangtuanya akan berkembang menjadi remaja yang memiliki kepribadian menarik, rasa percaya diri yang tinggi, kecerdasan emosi dan keterampilan sosial yang tinggi serta mampu menyelesaikan masalah dengan efektif (Megawangi, 2014; Akmalia \& Rahayuningsih, 2018)). Terdapat perbedaan antara ibu yang bekerja dan ibu yang tidak bekerja dalam pemberian ASI ekslusif. Ibu yang tidak bekerja mempunyai peluang lebih besar untuk memberikan ASI ekslusif daripada ibu yang bekerja (Dewi, 2017). Pemerintah mempunyai kewajiban untuk menjamin hak bayi agar mendapatkan Air Susu Ibu secara ekslusif (Wijaya \& Susanti, 2018).

Temuan penelitian sebelumnya menyatakan ibu yang bekerja diharapkan masih dapat memberikan waktu dan perhatian untuk mengasuh anak dan menyediakan quality time untuk 
berinteraksi dengan anak dalam melakukan kegiatan-kegiatan yang bermanfaat bagi pengoptimalan pertumbuhan dan perkembangannya karena pada penelitian ditemukan anak dari ibu tidak bekerja memiliki perkembangan sosial emosi yang tinggi daripada anak dari ibu bekerja (Wijirahayu et al, 2016). Berdasarkan permasalahan tersebut tujuan penelitian ini yaitu menganalisis Model Daycare di Perkantoran Berbasis Attachment, dengan daycare ini orangtua dapat dekat dan lekat dengan anak, tidak khawatir lagi bagaimana tumbuh kembang anak, terjamin keamanan dan kenyamanan anak karena di daycare ini orangtua bisa dengan cepat dan dekat memantau anak-anaknya, bisa menyusui secara maksimal, dan bisa tetap konsentrasi dalam bekerja (Hewi et al., 2019). Di samping itu orangtua tidak lagi bersedih setiap berpisah dengan anak, waktu bekerja orangtua optimal, tidak harus pulang untuk menyusui yang menyita waktu diperjalanan dan sekali dua jam bisa menyusui. Anak bisa setiap waktu dilihat, terutama jika sedang tidak banyak pekerjaan. Setiap waktu istirahat bisa bersama anak dan setiap pulang tidak harus terburu-buru menjemput anak.

\section{Metode}

Model yang digunakan dalam penelitian ini mengacu pada model 4-D, yang dikemukakan oleh Thiagarajan. Model ini terdiri dari empat tahap yaitu a) pendefenisian (define), b) perancangan (design), c) pengembangan (develop), dan d) penyebaran (disseminate) (Trianto, 2010). Penelitian dilakukan di Dinas Pendidikan Provinsi Sumatera Barat dengan responden adalah pejabat berjumlah 4 orang dan pegawai yang mempunyai anak usia dini (0 - 6 tahun) sebanyak 16 orang. Sementara untuk penyebaran dilakukan di Dinas Pemberdayaan Perempuan dan Perlindungan Anak Prov. Sumatera Barat dengan responden sebanyak 4 orang. Adapun instrumen pengumpulan data yang digunakan dalam penelitian pengembangan ini adalah Instrumen Validitas, Instrumen Kepraktisan, dan Instrumen Keefektifan. Sementara teknik analisis data penelitian menggunakan deskriptif kuantitatif, yaitu dengan cara mendiskripsikan tingkat validitas, praktikalitas dan efektifitas Model Daycare berbasis Attachment.

Tabel 1. Data dan Sumber Data

\begin{tabular}{lll}
\hline \multicolumn{1}{c}{ Instrumen } & \multicolumn{1}{c}{ Data } & \multicolumn{1}{c}{ Sumber Data } \\
\hline Instrumen Validitas & Skor Hasil Validasi Buku & Validator \\
Instrumen Praktikalitas & Skor Hasil Praktikalitas Buku & Pejabat dan pegawai \\
& Panduan & Pejabat dan pegawai \\
Instrumen Efektivitas & Skor Hasil Efektivitas Buku & Pejabat dan pegawai \\
\hline
\end{tabular}

Analisis validitas menggunakan skala Likert berdasarkan lembar validasi. Kategori validitas berdasarkan nilai akhir kemudian di presentasekan dengan skala $0 \%-100 \%$ seperti pada Tabel 2.

Tabel 2. Kategori Validitas Model Daycare di Perkantoran Berbasis Attachment

\begin{tabular}{cll}
\hline \multicolumn{2}{l}{ Interval } & Kategori \\
\hline $\mathbf{1 .}$ & $\mathbf{0 \%}-\mathbf{2 0 \%}$ & Tidak Valid \\
$\mathbf{2}$ & $\mathbf{2 1 \%}-\mathbf{4 0 \%}$ & Kurang Valid \\
3. & $\mathbf{1 \%}-\mathbf{6 0 \%}$ & Cukup Valid \\
$\mathbf{4 .}$ & $\mathbf{6 1 \%}-\mathbf{8 0 \%}$ & Valid \\
$\mathbf{5 .}$ & $\mathbf{8 1 \%}-\mathbf{1 0 0 \%}$ & Sangat Valid \\
\hline
\end{tabular}

Sumber: (Riduwan, 2009)

Analisis data praktikalitas meliputi analisis data hasil lembar angket respon pejabat dan pegawai terhadap buku panduan Pengembangan Model Daycare di Perkantoran yang berbasis Attachment seperti pada Tabel 3.

Tabel 3. Kategori Praktikalitas Model Daycare di Perkantoran Berbasis Attachment

\begin{tabular}{|c|c|}
\hline Interval & Kategori \\
\hline 1. $0 \%-20 \%$ & Tidak Praktis \\
\hline 2. $21 \%-40 \%$ & Kurang Praktis \\
\hline 3. $41 \%-60 \%$ & Cukup Praktis \\
\hline 4. $61 \%-80 \%$ & Praktis \\
\hline 5. $81 \%-100 \%$ & Sangat Praktis \\
\hline
\end{tabular}

Sumber: (Riduwan, 2009) 
Data analisis efektifitas Model Daycare Berbasis Attachment diperoleh dari instrumen pengumpulan data yaitu untuk mengetahui seberapa efektifnya program attachment pada daycare di perkantoran terhadap attachment orangtua dan anak seperti pada Tabel 4.

Tabel 4. Kategori Efektivitas Model Daycare di Perkantoran Berbasis Attachment

\begin{tabular}{|c|c|}
\hline Interval & Kategori \\
\hline 1. $0 \%-20 \%$ & Tidak efektif \\
\hline 2. $21 \%-40 \%$ & Kurang efekti \\
\hline 3. $41 \%-60 \%$ & Cukup efektif \\
\hline 4. $61 \%-80 \%$ & Efektif \\
\hline 5. $81 \%-100 \%$ & Sangat efektif \\
\hline
\end{tabular}

\section{Hasil dan Pembahasan}

Pada tahap pendefinisian (define) ini dilakukan analisis kebutuhan untuk mengetahui seberapa perlunya daycare berbasis attachment didirikan di perkantoran. Tahap analisis, melakukan analisis kebutuhan dengan cara melakukan observasi, wawancara dan survei kepada pegawai Dinas Pendidikan Prov. Sumbar dengan menggunakan instrumen, panduan wawancara dan dokumentasi. Beberapa kondisi di atas memperlihatkan bahwa di perkantoran perlu didirikan daycare dengan kegiatan yang mendukung attachment sehingga anak tidak rewel lagi, anak mendapatkan ASI yang full, anak dapat bermain dan makan bersama dengan orangtua, dan tumbuh kembangnya optimal. Buku panduan daycare perkantoran berbasis attachment dapat membantu pejabat maupun pegawai dalam mendirikan daycare mulai dari tahap awal pendirian sampai ke program dan kegiatan. Pada tahap perancangan (design) bertujuan untuk merancang buku panduan pengembangan model daycare di perkantoran berbasis attachment yang nantinya dapat dipergunakan oleh perkantoran dalam mendirikan daycare. Berdasarkan analisis pada tahap pendefinisian maka dilakukan perancangan terhadap buku panduan model daycare untuk meningkatkan attachment antara orangtua dan anak, dirumuskan tahap selanjutnya adalah merancang buku. Struktur atau bagian buku secara umum adalah cover, halaman Preliminaries, bagian Utama (Isi), dan bagian Postliminary.

Tahap desain, dilakukan desain cover pada buku panduan didominasi warna ungu tua dan ungu muda, terdapat gambar bayi dengan ekspresi sedang dijujai, gambar depan sebuah daycare, gambar orangtua sedang berkomunikasi dengan bayi, gambar ruang tidur dan ruang bermain daycare. Pemilihan warna ungu melambangkan kemewahan, keanggunan, dan kebijaksanaan. Sementara gambar dipilih sesuai dengan materi pada buku yang meliputi layanan pendidikan anak usia dini yaitu daycare, dan kegiatan yang meningkatkan attachment antara orangtua dan anak. Cover buku panduan memuat judul dan identitas untuk siapa buku ini dibuat dan identitas penyusun buku. Untuk lebih jelasnya desain cover buku panduan dapat dilihat pada gambar 1. Halaman Preliminaries yaitu halaman setelah cover sampai pada bagian utama, seperti halaman judul, halaman nama penulis, halaman kata pengantar dan daftar isi. Font untuk halaman judul adalah Baskerville Old Face dengan ukuran 48 agar pembaca lebih fokus terhadap judul. Untuk lebih jelasnya dapat dilihat pada gambar 2. Pada halaman nama penulis ukuran font 18 karena selain penulis, juga dituliskan nama editor dan nama penata cover. Untuk lebih jelasnya dapat dilihat pada gambar 3.

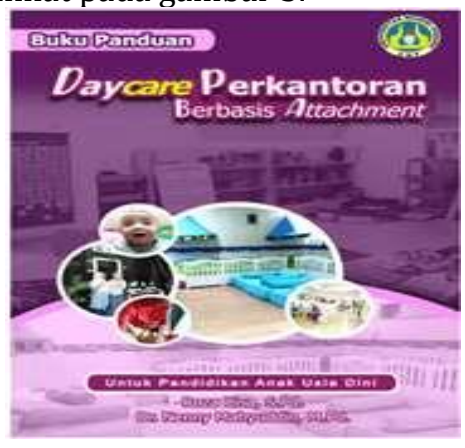

Gambar 1. Desain Cover pada Halaman Depan Buku Panduan

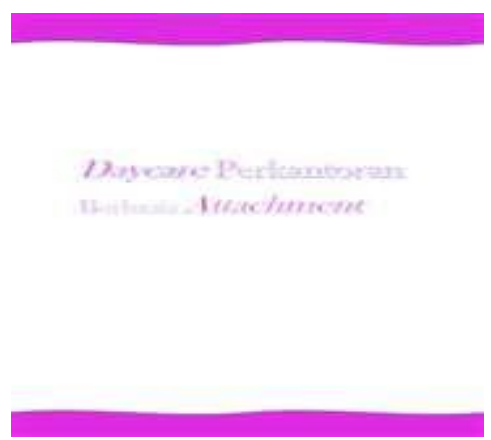

Gambar 2. Desain Halaman Judul

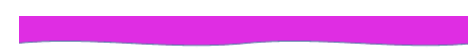

Gambar 3. Desain Halaman Nama Penulis, dkk

Pada halaman kata pengantar penulis mengucapkan ucapan syukur dan terimakasih kepada pihak yang telah membantu penyelesaian buku panduan. Halaman daftar isi berisi bab dan subbab beserta 
nomor halaman. Kata pengantar yang dibuat dalam buku panduan daycare perkantoran berbasis attachment ini memberikan gambaran singkat tentang tujuan kenapa buku panduan ini dirancang. Tulisan pada kata pengantar menggunakan jenis font Baskerville Old Face dengan ukuran 12. Untuk lebih jelasnya dapat dilihat pada Gambar 4. Daftar isi memuat halaman yang dapat memudahkan pengguna buku panduan daycare perkantoran berbasis attachment ke materi atau lembaran yang diinginkan. Tulisan pada daftar isi menggunakan jenis font Baskerville Old Face dengan ukuran 12. Untuk lebih jelasnya dapat dilihat pada Gambar 5.

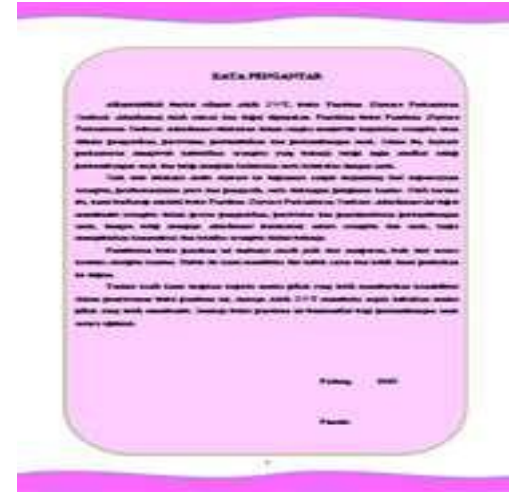

Gambar 4. Desain Kata Pengantar Buku Panduan

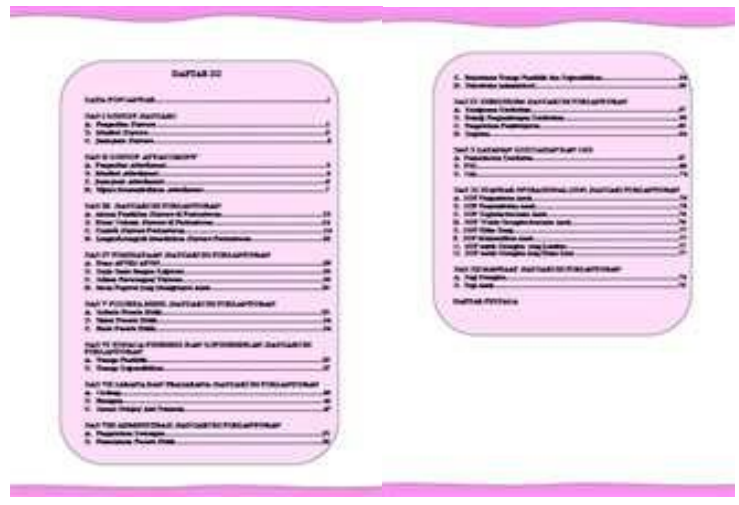

Gambar 5. Desain Daftar Isi Buku Panduan

Bagian utama adalah bagian materi atau isi, dimana pada bagian ini penulis memaparkan $12 \mathrm{BAB}$ yang terdiri dari beberapa subbab. Buku panduan ini mengupas tentang konsep daycare, konsep attachment, alasan didirikannya daycare di perkantoran, bagaimana langkah-langkah mendirikan daycare di perkantoran, bagaimana pembiayaan, peserta didik, tenaga pendidik dan kependidikan, sarana dan prasarana, administrasi, kurikulum daycare perkantoran, bagaimana layanan kesehatan dan gizi, standar operasional dan apa manfaat dari daycare di perkantoran. Buku panduan ini menggunakan font Baskerville Old Face dengan ukuran 14 pada judul bab dan ukuran 12 untuk bagian isi. Penomoran untuk halaman ganjil dibagian pojok bawah sebelah kanan, sementara halaman genap dibagian pojok bawah sebelah kiri.

Bagian postliminary adalah bagian akhir buku panduan. Salah satu bagian postliminary adalah daftar pustaka. Daftar pustaka berisi daftar sumber informasi materi. Daftar pustaka ini dapat digunakan pembaca buku untuk menelusuri informasi sumber dan melakukan pendalaman dan pengembangan pengetahuan tentang daycare perkantoran berbasis attachment.

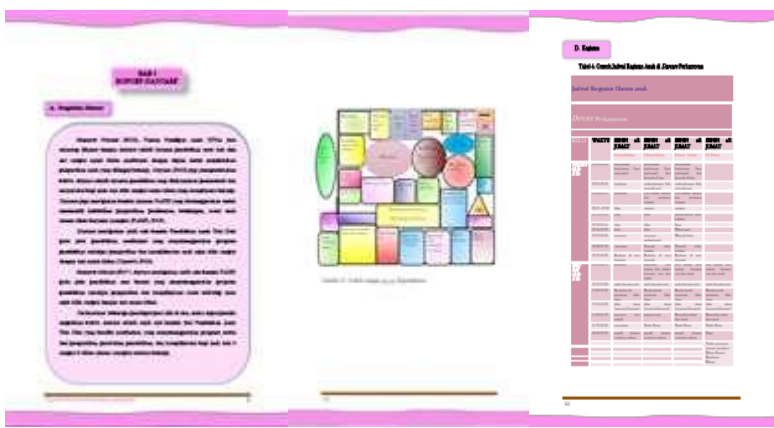

Gambar 6. Desain Bagian Isi

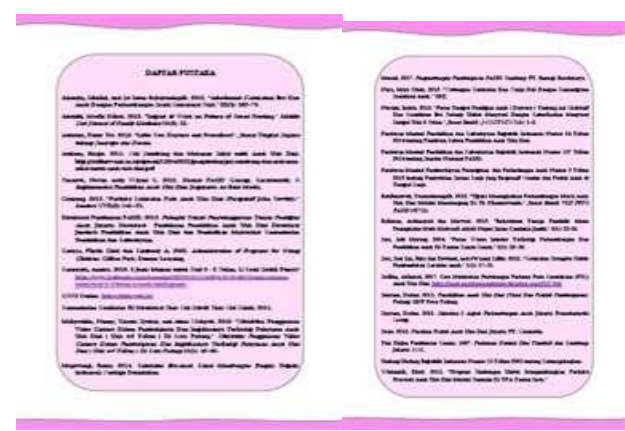

Gambar 7. Desain Daftar Pustaka Buku Panduan

Pada tahap pengembangan bertujuan untuk menghasilkan buku panduan pengembangan model daycare di perkantoran yang valid, praktis dan efektif, sehingga layak digunakan. Tahapan pengembangan ini terdiri dari tiga tahap yaitu tahap validasi, tahap uji praktikalitas dan tahap uji efektifitas. Berikut akan disajikan masing-masing tahap. Buku panduan dirancang kemudian divalidasi oleh validator. Validasi dilakukan oleh tiga orang validator ahli. Pada tahap ini validator ahli diminta untuk menilai buku panduan yang sudah dibuat. Penilaian mencakup konten (isi), tampilan (desain) serta bahasa dan keterbacaan. Buku panduan yang sudah direvisi diserahkan kepada validator. Validator diminta untuk memberikan penilaian dan pendapat terhadap buku panduan yang sudah direvisi. Validasi dilakukan terhadap 
beberapa aspek yaitu aspek konten (isi), aspek tampilan (desain) serta aspek bahasa dan keterbacaan. Hasil validasi dapat dilihat pada Tabel 5 .

Tabel 5. Hasil Uji Validitas Buku Panduan

\begin{tabular}{llcc}
\hline No. & Kriteria Penilaian & Validitas (\%) & Kategori \\
\hline $\mathbf{1}$ & Aspek isi (konten) & 85,7 & Sangat Valid \\
$\mathbf{2}$ & Aspek bahasa/ keterbacaan & 84 & Sangat Valid \\
$\mathbf{3}$ & Aspek desain & 92 & Sangat Valid \\
\hline Total rata-rata & $\mathbf{8 7}$ & Sangat Valid \\
\hline
\end{tabular}

Berdasarkan tabel di atas dapat dilihat bahwa rata-rata skor penilaian buku panduan daycare perkantoran berbasis attachment diperoleh dari tiga kriteria yaitu aspek isi (konten), aspek bahasa dan keterbacaan dan aspek tampilan (desain). Dari ketiga kriteria penilaian didapatkan total nilai validasi buku panduan adalah sebesar 87 \% dengan kategori sangat valid. Dari hasil validitas secara keseluruhan menunjukkan bahwa buku panduan yang telah dikembangkan sudah memiliki kualitas yang baik dan dapat dipercaya atau absah (valid) untuk digunakan sebagai panduan bagi perkantoran untuk mendirikan daycare dengan basis attachment. Hasil pengolahan data validasi buku panduan daycare perkantoran untuk meningkatkan attachment antara orangtua dan anak dapat dilihat pada lampiran. Setelah buku panduan dinyatakan valid, langkah berikutnya yaitu mengetahui praktikalitas buku panduan. Untuk mengetahui praktis atau tidaknya buku panduan daycare perkantoran maka dilakukan melalui pengisian angket oleh pejabat dan pegawai. Hasil penilaian respon tersebut terhadap praktikalitas buku panduan dapat dilihat pada Tabel 6 .

Tabel 6. Hasil Uji Praktikalitas Buku Panduan

\begin{tabular}{llcc}
\hline No & Indikator yang dinilai & Presentase Kepraktisan (\%) & Kategori \\
\hline A & Praktikalitas Pengguna & 89,2 & Sangat Praktis \\
B & Kesesuaian Ilustrasi & 84 & Sangat Praktis \\
C & Bahasa & 89,5 & Sangat Praktis \\
\hline Rata-rata & $\mathbf{8 8}$ & Sangat Praktis \\
\hline
\end{tabular}

Berdasarkan tabel di atas terlihat bahwa dari 3 indikator praktikalitas yang dinilai oleh pejabat dan pegawai menunjukkkan hasil rata-rata keseluruhan penilaian praktikalitas respon pejabat dan pegawai terhadap buku panduan adalah $88 \%$ dengan kategori sangat praktis. Ini artinya buku panduan yang dikembangkan telah memiliki kepraktisan baik dari penyajian maupun penggunaannya. Dengan demikian dapat disimpulkan bahwa praktikalitas buku panduan pengembangan model daycare di perkantoran berbasis attachment berdasarkan hasil angket respon pejabat dan pegawai dikategorikan sangat praktis.

Uji efektifitas buku panduan, tingkat keberhasilan dari penggunaan buku panduan model daycare di perkantoran berbasis attachment dilakukan dengan menyebar angket kepada pegawai yang berusia produktif (yang mempunyai anak usia $0-6$ tahun) setelah memperkenalkan buku beserta program daycare kepada pegawai. Hasil uji efektifitas program dapat diamati pada Tabel 7. Berdasarkan Tabel 7 terlihat bahwa program yang dimiliki daycare di perkantoran menunjukkan angka yang dikategorikan sangat efektif. Ini artinya buku panduam yang dikembangkan telah memiliki keefektifan baik dari penyajian maupun penggunanya. Dengan demikian dapat disimpulkan bahwa buku panduan model daycare di perkantoran sangat efektif untuk meningkatkan attachment antara orangtua dan anak.

Tabel 7. Hasil Uji Efektifitas (Respon Pejabat dan Pegawai)

\begin{tabular}{llcc}
\hline No & \multicolumn{1}{c}{ Aspek Yang Dinilai } & $\begin{array}{c}\text { Persentase } \\
\text { Efektifitas (\%) }\end{array}$ & Kategori \\
\hline 1. & $\begin{array}{l}\text { Penyambutan anak dimulai pukul 07.00, kecuali bagi } \\
\text { yang ada keperluan sebelum jam 07.00 dengan }\end{array}$ & 82 & Sangat Efektif \\
$\begin{array}{l}\text { menginformasikan terlebih dahulu. } \\
\text { 2. Setiap pagi anak berjemur dan melakukan kegiatan fisik } \\
\text { (motorik/seni) }\end{array}$ & 90 & Sangat Efektif \\
3. Pemberian ASI untuk anak 0-6 bulan per 2 jam atau \\
sesuai kebutuhan bayi dengan menginformasikan melalui
\end{tabular}
wa 
4. Anak dibiasakan cuci tangan, berdo'a setiap mau makan dan setiap memulai aktivitas.

5. Anak diajarkan toilet training sekitar umur 18 bulan sampai 2 tahun (tergantung kesiapan anak).

6. Perkembangan kognitif, bahasa, fisik motorik, sosial emosional, agama, dan seni anak selalu distimulus melalui kegiatan bermain sambil belajar.

7. Orangtua dapat melihat aktivitas anak melalui hp yang terhubung dengan CCTV/ wa video call/ zoom meeting

8. Orangtua bermain bersama dengan anak pada jam istirahat orangtua

9. Orangtua makan bersama dengan anak pada jam istirahat orangtua

10. Anak dibiasakan shalat, terutama waktu dzuhur dan ashar

11. Kemandirian anak dilatih terutama untuk kebersihan dan kerapian diri

12. Anak-anak tidur siang setiap hari dengan didongengkan/ diputarkan murrotal oleh pengasuh.

13. Orangtua memandikan anak sebelum pulang, kecuali jika orangtua berhalangan dengan mengkonfirmasi terlebih dahulu.

14. Standar pulang anak jam 17.00 kecuali jika ortu lembur/ dinas luar/ ada keperluan, dengan mengkonfirmasikan terlebih dahulu.
93

Sangat Efektif

Sangat Efektif

Sangat Efektif

Sangat Efektif

Sangat Efektif

Sangat Efektif

Sangat Efektif

Sangat Efektif

Sangat Efektif

Sangat Efektif

Sangat Efektif

88

Sangat Efektif

Pada tahap penyebaran merupakan tahap penggunaan buku panduan pada ruang lingkup yang lebih luas. Penyebaran ini dapat dilakukan pada kantor lain. Pada penelitian ini penyebaran dilakukan pada Dinas Pemberdayaan Perempuan dan Perlindungan Anak Provinsi Sumatera Barat. Tujuannya adalah untuk menguji efektifitas program daycare pada objek, situasi dan kondisi yan berbeda. Tahap penyebaran dilakukan pada tanggal 16 Oktober 2020 di Dinas Pemberdayaan Perempuan dan Perlindungan Anak Provinsi Sumatera Barat. Penerapan uji efektifitas yang dilakukan pada tahap penyebaran sama halnya ketika uji efektifitas program dilakukan yaitu dengan pengenalan buku dan pengisian angket. Data hasil angket secara rinci disajikan pada Tabel 8.

Tabel 8. Hasil Uji Efektifitas Tahap Penyebaran (Respon Pejabat dan Pegawai Dinas Pemberdayaan Perempuan dan Perlindungan Anak Provinsi Sumatera Barat)

\begin{tabular}{|c|c|c|c|}
\hline No & Aspek Yang Dinilai & $\begin{array}{c}\text { Persentase } \\
\text { Efektifitas \% }\end{array}$ & Kategori \\
\hline 1. & $\begin{array}{l}\text { Penyambutan anak dimulai pukul } 07.00 \text {, kecuali bagi } \\
\text { yang ada keperluan sebelum jam } 07.00 \text { dengan } \\
\text { mengkonfirmasi terlebih dahulu. }\end{array}$ & 93,3 & Sangat Efektif \\
\hline 2. & $\begin{array}{l}\text { Setiap pagi anak berjemur dan melakukan kegiatan fisik } \\
\text { (motorik/ seni) }\end{array}$ & 90 & Sangat Efektif \\
\hline 3. & $\begin{array}{l}\text { Pemberian ASI untuk anak } 0-6 \text { bulan per } 2 \text { jam atau } \\
\text { sesuai kebutuhan bayi dengan menginformasikan melalui } \\
\text { wa }\end{array}$ & 90 & Sangat Efektif \\
\hline 4. & $\begin{array}{l}\text { Anak dibiasakan cuci tangan, berdo'a setiap mau makan } \\
\text { dan setiap memulai aktivitas. }\end{array}$ & 100 & Sangat Efektif \\
\hline 5. & $\begin{array}{l}\text { Sejak anak mulai pandai berjalan, anak dilatih toilet } \\
\text { training }\end{array}$ & 93,3 & Sangat Efektif \\
\hline 6. & $\begin{array}{l}\text { Perkembangan kognitif, bahasa, fisik motorik, sosial } \\
\text { emosional, agama, dan seni anak selalu distimulus } \\
\text { melalui kegiatan bermain sambil belajar. }\end{array}$ & 90 & Sangat Efektif \\
\hline 7. & $\begin{array}{l}\text { Orangtua dapat melihat aktivitas anak melalui hp yang } \\
\text { terhubung dengan CCTV/ wa video call/ zoom meeting }\end{array}$ & 93,3 & Sangat Efektif \\
\hline 8. & Orangtua bermain bersama dengan anak pada jam & 86,7 & Sangat Efektif \\
\hline
\end{tabular}


istirahat orangtua

9. Orangtua makan bersama dengan anak pada jam istirahat orangtua

10. Anak dibiasakan shalat, terutama waktu dzuhur dan ashar.

11. Kemandirian anak dilatih terutama untuk kebersihan dan kerapian diri

12. Anak-anak tidur siang setiap hari.

13. Orangtua memandikan anak sebelum pulang, kecuali jika orangtua berhalangan dengan mengkonfirmasi terlebih dahulu.

14. Standar pulang anak jam 17.00 kecuali jika ortu lembur/ dinas luar/ ada keperluan, dengan mengkonfirmasikan terlebih dahulu.

$\begin{array}{ll}\mathbf{8 6 , 7} & \text { Sangat Efektif } \\ 96,7 & \text { Sangat Efektif } \\ 93,3 & \text { Sangat Efektif } \\ & \\ 93,3 & \text { Sangat Efektif } \\ 76,7 & \text { Efektif }\end{array}$

93,3 Sangat Efektif

Tabel 8 menggambarkan bahwa program daycare memiliki rata-rata persentase $91 \%$ dengan kategori sangat efektif. Hal ini dapat dikatakan bahwa program daycare sangat bagus dalam rangka meningkatkan attachment antara orang tua dan anak. Dengan demikian buku panduan sudah bisa dipergunakan untuk perkantoran lain yang pegawainya mempunyai anak usia dini (0-6 tahun) yang membutuhkan daycare demi optimalnya attachment antara orangtua dan anak.

Berdasarkan hasil penelitian program daycare ini sangat efektif digunakan dalam rangka meningkatkan attachment antara orang tua dan anak. Hal ini dapat dilihat dari beberapa aspek. Pertama, dilihat dari aspek kebutuhan yaitu Buku panduan daycare perkantoran berbasis attachment dapat membantu pejabat maupun pegawai dalam mendirikan daycare mulai dari tahap awal pendirian sampai ke program dan kegiatan. Daycare merupakan layanan bagi anak-anak yang orang tuannya bekerja. Tujuannya agar anak-anak tetap mendapatkan pemenuhan hak anak, terutama hak atas pengasuhan yang optimal selama orangtua selama bekerja. Layanan yang diberikan termasuk pengasuhan anak yang menitikberatkan pada kesehatan fisik dan mental, karakter positif anak, hubungan/relasi sosial, kepedulian terhadap lingkungan, kemampuan berbahasa, aspek kognitif, serta kreativitas dan seni (Kristiani et al., 2021; Nuraini, 2018).

Dilihat aspek desain, buku panduan ini disajikan dengan sederhadan. Dilengkapi materi tentang konsep daycare, konsep attachment, alasan didirikannya daycare di perkantoran, bagaimana langkahlangkah mendirikan daycare di perkantoran, bagaimana pembiayaan, peserta didik, tenaga pendidik dan kependidikan, sarana dan prasarana, administrasi, kurikulum daycare perkantoran, bagaimana layanan kesehatan dan gizi, standar operasional dan apa manfaat dari daycare di perkantoran. Selain itu, tingkat keberhasilan dari penggunaan buku panduan model daycare di perkantoran berbasis attachment dilakukan dengan menyebar angket kepada pegawai yang berusia produktif (yang mempunyai anak usia 0 - 6 tahun) setelah memperkenalkan buku beserta program daycare kepada pegawai. Buku panduam yang dikembangkan telah memiliki keefektifan baik dari penyajian maupun penggunanya. Program fullday adalah program yang sangat sesuai dengan daycare yang berada di lingkungan perkantoran, hanya saja diperlukan dukungan dari semua pihak agar berjalan lancar (AZIZ, 2017). Daycare harus memenuhi standar sarana dan prasarana yang baik dan lengkap (Widiastuti, 2018). Berdasarkan hal tersebut buku panduan ini sangat layak digunakan dalam mendirikan program daycare.

\section{Simpulan}

Hasil pengembangan buku panduan daycare perkantoran berbasis attachment sudah dinyatakan valid, praktis dan efektif dapat meningkatkan attachment orangtua dan anak yang dapat digunakan oleh pejabat dan pegawai di perkantoran yang akan mendirikan daycare di perkantoran.

\section{Daftar Rujukan}

Akmalia, I., \& Rahayuningsih, S. I. (2018). Attachment (kelekatan) Ibu dan Anak dengan Perkembangan Sosial Emosional Bayi. Jurnal Ilmiah Mahasiswa Fakultas ..., III(3), 365-370. http://www.jim.unsyiah.ac.id/FKep/article/view/8546.

AZIZ, A. (2017). Implementasi Inovasi Pada Model-Model Pendidikan Anak Usia Dini di Taman 
Pengasuhan Anak (TPA) Serama Kementerian Kesehatan RI. JPUD - Jurnal Pendidikan Usia Dini, 11(2), 201-214. https://doi.org/10.21009/jpud.112.01.

Dewi, P. S. (2017). Ibu yang Bekerja dan Ibu yang Tidak Bekerja dalam Pemberian ASI Eksklusif di Desa Karangpakis, Kec. Kabuh, Kab. Jombang. Midwifery Journal Of STIKES Insan Cendekia Medika Jombang, 14(1), 15-20.

Ervika, E. (2005). Kelekatan (Attachment) Pada Anak. 1-17.

Hewi, L., Saleh, M., \& Wahyuni, R. (2019). Kelekatan (attachment) anak usia dini di Suku Laut Kabupaten Wakatobi. Jurnal Obsesi: Jurnal Pendidikan Anak Usia Dini, 4(1), 406-415. https://doi.org/10.31004/obsesi.v4i1.346.

Izza, H. (2020). Meningkatkan Perkembangan Sosial Anak Usia Dini melalui Metode Proyek. Jurnal Obsesi : Jurnal Pendidikan Anak Usia Dini, 4(2), 951. https://doi.org/10.31004/obsesi.v4i2.483.

Karkos, P. C. dan K. A. (2008). Administration of Programs for Young Children. Delmar Learning.

Kristiani, R., Handayani, P., Wolting, R., Ardani, A., \& Nicholas, D. (2021). Pengembangan Kapasitas Pengasuh dan Orang Tua Daycare Rumah Bahagia Surabaya. Warta LPM, 24(2), 258-269. https://doi.org/10.23917/warta.v24i2.12343.

Mahyuddin, N., Syukur, Y., \& Hidayati, A. (2016). Efektivitas Penggunaan Video Camera Dalam Pembelajaran Dan Implikasinya Terhadap Pelayanan Anak Usia Dini ( Usia 4-6 Tahun ) Di Kota Padang. JPUD - Jurnal Pendidikan Usia Dini, 10(1), 45-60. https://doi.org/10.21009/jpud.101.03.

Malinton, S. (2013). Studi Tentang Pelayanan Anak di Taman Penitipan Anak Puspa Wijaya I Tenggarong. EJournal Sosiatri-Sosiologi, 1(2), 36-50.

Megawangi, R. (2014). Kelekatan Ibu-Anak "Kunci Membangun Bangsa." Depok: Indonesia Heritage Foundation (IHF).

Nuraini, I. (2018). Peran Tempat Penitipan Anak ( Daycare ) Tentang Asi Eksklusif Dan Komitmen Ibu Bekerja Untuk Menyusui Dengan Keberhasilan Menyusui Sampai Usia 6 Bulan. J-HESTECH (Journal Of Health Educational Science And Technology), 1(1), 1. https://doi.org/10.25139/htc.v1i1.990.

Rakimahwati, Y. (2012). Upaya Meningkatkan Perkembangan Moral Anak Usia Dini Melalui Mendongeng Di Tk Dharmawanita Improving the Moral Development of Early Age Children. Ilmiah Visi P2TK PAUD NI, 7(1), 18-41. http://webcache.googleusercontent.com/search?q=cache:STZdc_RLneMJ:journal.unj.ac.id/unj/inde x.php/jiv/article/download/2675.

Riduwan. (2009). Belajar Mudah Penelitian untuk Guru-Karyawan dan Peneliti Pemula. Alfabeta.

Rizkita, D. (2017). Pengaruh Standar Kualitas Taman Penitian Anak ( TPA ) Terhadap Motivasi dan Kepuasaan Orangtua ( Pengguna ) untuk Memilih Pelayanan TPA yang Tepat. EARLY CHILDHOOD: JURNAL PENDIDIKAN, 1(1), 28-43. https://doi.org/10.35568/earlychildhood.v1i1.46.

Sukatin, Q. Y. H., Alivia, A. A., \& Bella, R. (2020). Analisis Psikologi Perkembangan Sosial Emosional Anak Usia dini. Bunayya: Jurnal Pendidikan Anak, 6(2), 156-171. https://jurnal.arraniry.ac.id/index.php/bunayya/article/view/7311/4306.

Suryana, D. (2013). Pendidikan Anak Usia Dini (Teori dan Praktik Pembelajaran). UNP Press Padang.

Trianto, M. P. (2010). Model Pembelajaran Terpadu. Bumi Aksara.

Widiastuti, A. A. (2018). Implementasi Standar Sarana Dan Prasarana Paud Di Lembaga Taman Penitipan Anak (Tpa). PAUDIA : Jurnal Penelitian Dalam Bidang Pendidikan Anak Usia Dini, 7(1), 139-147. http://journal.upgris.ac.id/index.php/paudia/article/view/3462/2317.

Wijaya, P. S., \& Susanti, E. M. (2018). Kajian Implementasi Kebijakan Ruang Laktasi di PT Royal Korindah Kabupaten Purbalingga Tahun 2017. Indonesia Jurnal Kebidanan, 2(1), 1. https://doi.org/10.26751/ijb.v2i1.426.

Wijirahayu, A., Pranaji, D. K., \& Muflikhati, I. (2016). Kelekatan Ibu-Anak, Pertumbuhan Anak, dan Perkembangan Sosial Emosi Anak Usia Prasekolah. Jurnal Ilmu Keluarga Dan Konsumen, 9(3), 171182. https://doi.org/10.24156/jikk.2016.9.3.171. 